\title{
СТРАТЕГІЧНІ ПРОБЛЕМИ ДИВЕРСИФІКУВАННЯ В ЕНЕРГЕТИЧНОМУ СЕКТОРІ ЕКОНОМІКИ УКРАЇНИ ТА ПЕРСПЕКТИВИ ЇХ ВИРІШЕННЯ В УМОВАХ ЄВРОІНТЕГРУВАННЯ
}

\section{STRATEGIC PROBLEMS OF DIVERSIFICATION IN THE ENERGY SECTOR OF THE ECONOMY OF UKRAINE AND PROSPECTS OF THEIR SOLUTION IN THE CONTEXT OF EUROPEAN INTEGRATION}

\author{
Микитин Олег Зеновійович \\ кандидат технічних наук, доцент, \\ Національний університет «Львівська політехніка» \\ ORCID: https://orcid.org/0000-0001-9016-6757
}

\author{
Mykytyn Oleh \\ Lviv Polytechnic National University
}

\begin{abstract}
Стаття присвячена сутності диверсифрікування в енергетичному секторі економіки України, актуальним проблемам фрормування енергетичного балансу країни. Проаналізовано динаміку часток відновлювальних джерел енергії в загальних обсягах енергоспоживання в Україні. Досліджено структуру енергетичного балансу, його диспропорції. Визначено сутність диверсифікування в енергетичному секторі України, яке потрібно здійснювати згідно європейським стандартам, принципам, нормативам із урахуванням тісних взаємозв'язків між диверсисрікуванням природних енергетичних ресурсів, шляхів їх постачання тощо і рівнем енергетичної безпеки країни. Наведено перспективи диверсифрікування в енергетичному секторі України в умовах євроінтегрування. Запропоновано здійснювати диверсифрікування в енергетичному секторі України еволюційно, структуровано, комплексно, багатоаспектно, цілеспрямовано, емерджентно, динамічно, синергійно.

Ключові слова: енергетичні ресурси, енергетичний баланс, диверсифікування, енергетичний сектор, євроінтегрування, відновлювальна енергетика, енергетична стратегія.

Статья посвящена сущности диверсификации в энергетическом секторе экономики Украины, актуальным проблемам формирования энергетического баланса страны. Проанализирована динамика долей возобновляемых источников энергии в общих объемах энергопотребления в Украине. Исследована структура энергетического баланса, его диспропорции. Определена сущность диверсиоикации в энергетическом секторе Украины, которая должна осуществляться согласно европейским стандартам, принципам, нормативам с учетом тесных взаимосвязей между диверсификацией природных энергетических ресурсов, путей их снабжения и т.д. и уровнем энергетической безопасности страны. Приведены перспективы диверсификации в энергетическом секторе Украины в условиях евроинтегрирования. Предложено осуществлять диверсисикацию в энергетическом секторе Украины эволюционно, структурированно, комплексно, многоаспектно, целенаправленно, эмерджентно, динамично, синергично.
\end{abstract}

Ключевые слова: энергетические ресурсы, энергетический баланс, диверсификация, энергетический сектор, евроинтегрирование, возобновляемая энергетика, энергетическая стратегия.

The article is devoted to the essence of diversification in the energy sector of the Ukrainian economy, topical problems of the formation of the country's energy balance. The dynamics of the share of renewable energy sources in the total energy consumption in Ukraine have been analyzed. Energy (energy sector) is a crucial type of economic activity of any country. Effective functioning of the energy sector is essential for stabilizing and restructuring Ukraine's economy. Harmonious development of the energy market contributes to increasing the state's energy security (security), as one of the key elements of national security. The issue of diversification of energy supply became especially relevant at the stage of reforming the energy sector. Diversification is a complex, multifaceted phenomenon that must be fully integrated with all processes of the national economy. Therefore, energy diversification requires exceptionally detailed research considering the following aspects: economic, environmental, production, technical, 
managerial, etc. The structure of the energy balance and its imbalances have been investigated. The essence of diversification in the energy sector of Ukraine has been determined, which should be carried out following European standards, principles, regulations, taking into account the close relationships between the diversification of natural energy resources, their supply routes, etc. and the level of energy security of the country. The prospects for diversification in the energy sector of Ukraine in the context of European integration are given. It is proposed to carry out diversification in the energy sector of Ukraine in an evolutionary, structured, complex, multidimensional, purposeful, emergent, dynamic, synergistic manner. Diversification of ways and sources of energy supply in Ukraine should take place exclusively on the market, competitive basis. Today's Ukrainian choice will be crucial for the harmonious development of energy, economy, and climate improvement in a few years. Harmonious development of the country's economy is possible only under coordination and acceleration of efforts to promote energy transformation.

Keywords: energy resources, energy balance, diversification, energy sector, European integration, renewable energy, energy strategy.

Постановка проблеми. Загальновідомо, що саме енергетика (енергетичний сектор) $€$ ключовим видом економічної діяльності будь-якої з країн. Ефрективне фрункціонування енергетичного сектору вкрай необхідне для стабілізування, реструктурування економіки України. гармонійний розвиток енергетичного ринку сприяє підвищенню рівня енергетичної безпеки (захищеності) держави, як одного із ключових елементів національної безпеки. За умов катастрофрічного зменшення світових запасів традиційних енергоресурсів актуальним питанням виступає диверсисрікування енергопостачання. А у зв'язку із тенденціями загального погіршення екологічної ситуації актуальним $\epsilon$ активізування розвитку виробництва енергетичних носіїв із відновлюваних джерел енергії, альтернативних видів палива тощо, що у свою чергу є ключовим напрямком диверсисрікування енергопостачання.

Аналіз останніх досліджень і публікацій. Дослідження сутності, видів та значення диверсифрікування діяльності відображено в працях таких фрахівців як: Богуславський $€$.І. [2], Дрималовська Х.В. [5], Корінько М.Д. [9], Кузьмін О.Є. [5], Передало Х.С. [5], Черниченко А.О. [2], а також інші.

Проблемами і перспективами розвитку енергетики, включаючи й альтернативну, як один із потенційних та оптимальних напрямків диверсифрікування досліджують такі вчені як: Гаркуша В.В. [13], Домашенко М.Д. [4], Домашенко В.С. [4], Завербний А.С. [7], Троян М.Ю. [4], Школа В.Ю. [4], Шпак Ю.Н. [7], Яковенко В.С. [13] та інші.

Проблематиці диверсифікування енергопостачання в економіці присвячені праці таких фрахівців як Амоша O.I. [1], Бєлопольский Н.Г. [1], Борисяк О.В. [3], Завербний А.С. [7], Іванечко Н.Р. [3], Турченко Д.К. [1], Федоренко В.Г. [1], Шпак Ю.Н. [7] та інші.

Виділення невирішених раніше частин загальної проблеми. В той же час окремі теоретико-методологічні аспекти диверсифі- кування енергопостачання економіки України потребують додаткового дослідження із урахуванням динаміки, перспектив що виникають за умов євроінтегрування.

Формулювання цілей статті (постановка завдання). Основними завданнями статті виступають ідентифрікування стратегічних проблем диверсисрікування в енергетичному секторі економіки України в умовах євроінтегрування, виявлення перспективи щодо їх вирішення.

Виклад основного матеріалу дослідження. Як показує дослідження, енергетичний баланс України за 2019 р. (новітні дані за 2020 р. покищо відсутні на офріційному сайті Державної служби статистики України [11]) $€$ надто диспропорційним (тяжіє) у сторону традиційних енергоресурсів (рис. 1).

Можна чітко побачити, що значна частка у енергетичному балансі України за 2019 р. припадає саме на викопні енергетичні ресурси (рис. 1). Аналогічна ситуація була і в попередніх роках. Тобто процес диверсифрікування енергетичних ресурсів відбувається в Україні занадто повільно. Частки відновлювальних джерел енергії у загальних обсягах енергоспоживання в Україні (рис. 2) є надзвичайно низькими [11].

Забезпечення високого рівня ефрективності діяльності енергетичного сектору країни, підвищення його рівня рентабельності, екологічності та ін. виступає сьогодні одним із основних завдань, які постали перед енергетичною галуззю та економікою країни загалом.

Питання диверсиорікування енергопостачання стало особливо актуальним саме на етапі реформування енергетичного сектору, фрормуванні нових моделей газового, електроенергетичного та інших ринків України.

При чому на відміну від терміну «диверсифрікація», що носить статичний характер, пропонуємо саме поняття «диверсифікування», як динамічний процес. Оскільки одномоментна диверсифрікація не сприятиме досяг- 


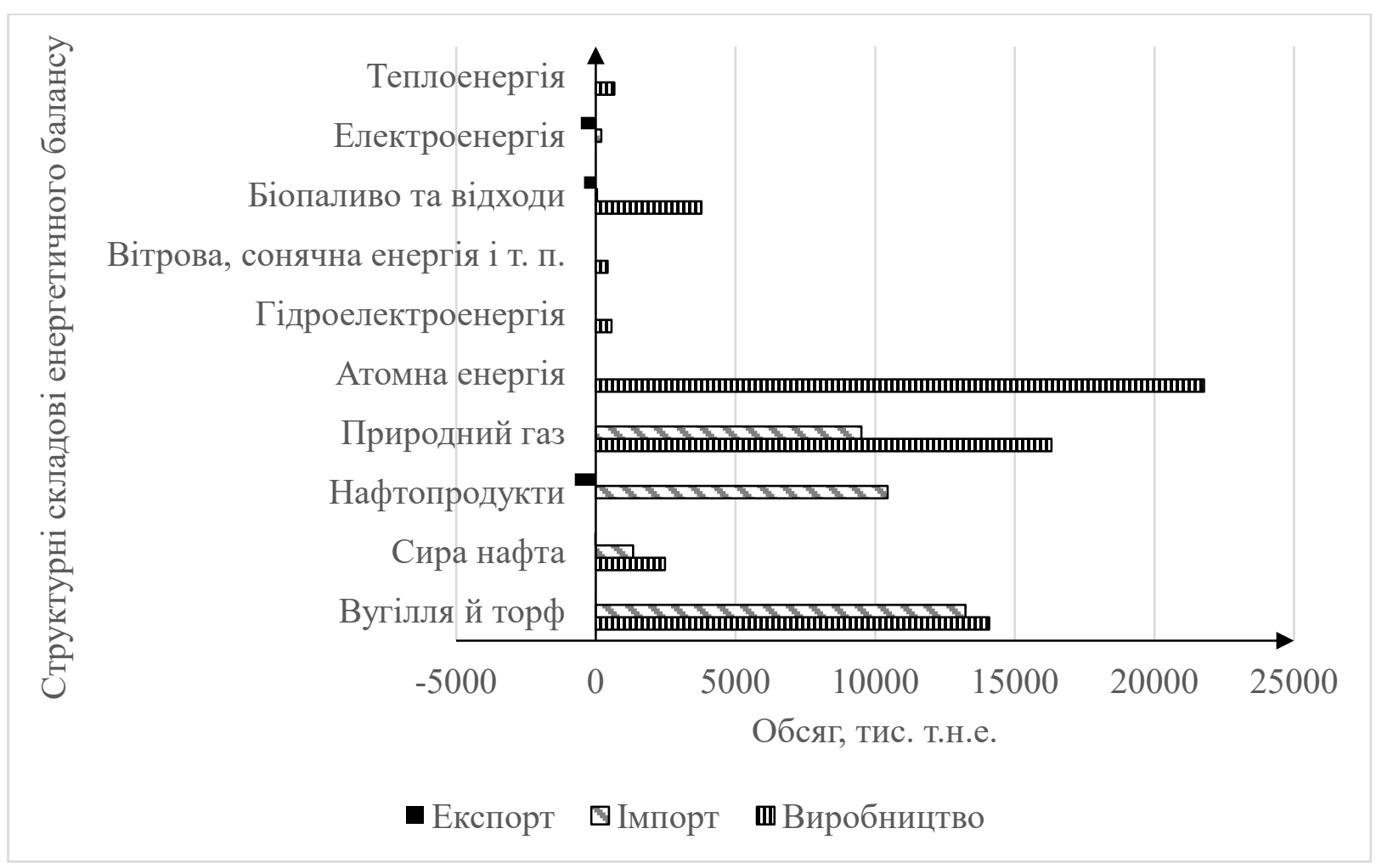

Рис. 1. Структура енергетичного балансу України у 2019 р.

Джерело: [10; 11]

ненню позитивних змін. Даний процес має мати постійний характер в залежності від динамічного зовнішнього середовища (винайдення альтернативних джерел, суттєве здорожчання певного виду енергоресурсу тощо).
Диверсифрікування являє собою комплексне багатогранне явище, що повинне повністю інтегруватися з усіма процесами національної економіки. Тому енергетичне диверсифікування потребує особливо детального дослід-

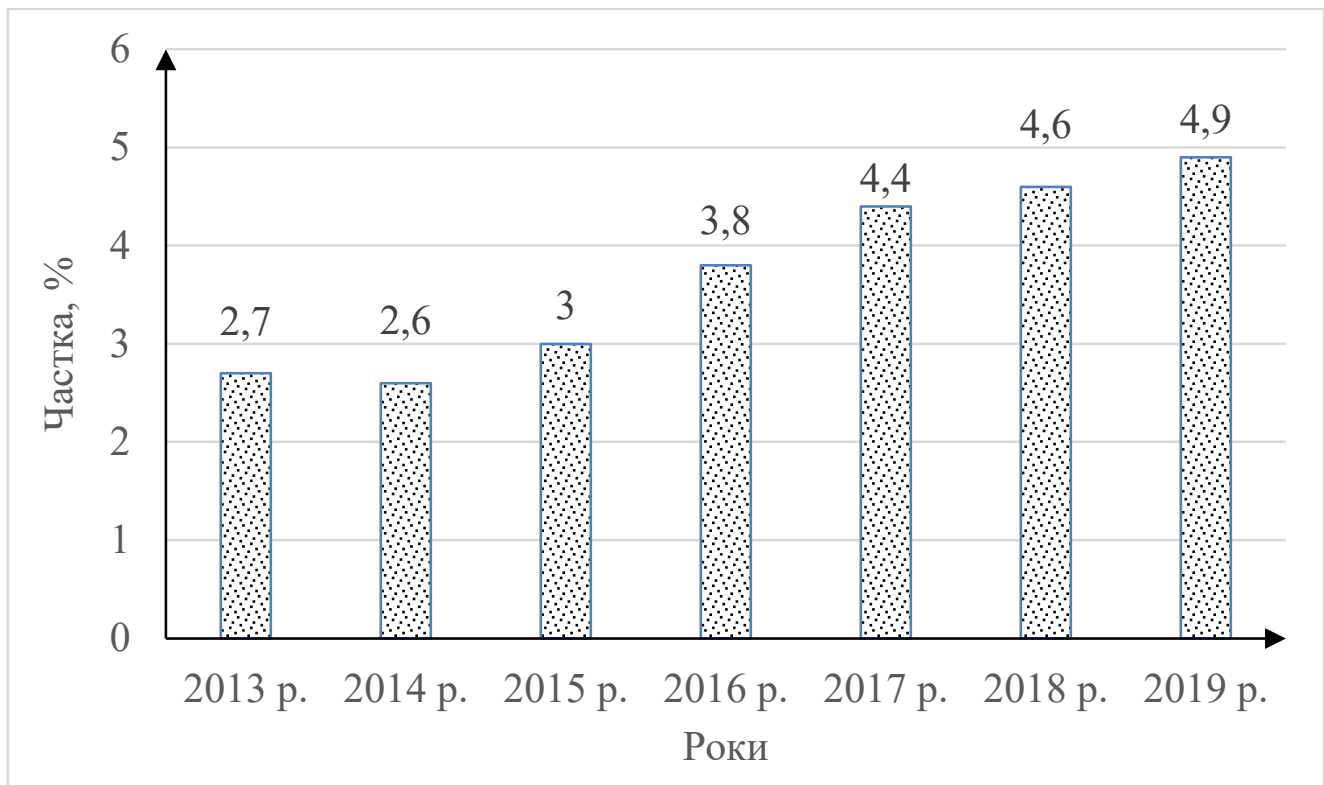

Рис. 2. Динаміка частки відновлювальних джерел енергії В загальних обсягах енергоспоживання в Україні протягом 2013-2019 pp. 
ження із врахуванням таких аспектів: економічних, екологічних, виробничих, технічних, управлінських та ін.

Диверсифікування в енергетичному секторі України потрібно здійснювати згідно європейським стандартам, принципам, нормативам із урахуванням тісних взаємозв'язків між диверсифікуванням природних енергетичних ресурсів, шляхів їх постачання тощо і рівнем енергетичної безпеки країни.

Стабільний рівень забезпеченості енергетичними ресурсами можливий лишень за умов структурного, ефрективного рефрормування українського енергетичного сектору (зокрема й диверсифікуванню, як одного із ключових інструментів ефрективних рефрорм). Однак, поки що реформування відбувається занадто повільно, неузгоджено, фррагментарно (передусім мова йде лише про ринки природного газу та електроенергії). Суттєвою проблемою виступають високі рівні корумпованості, недовіри, що перешкоджає забезпеченню належного рівня диверсифікування енергопостачання.

Ефективне диверсифрікування (енрегоресурсів, шляхів їх торимання) в енергетичному секторі сприятиме виходу його на якісно вищий рівень фрункціонування, зниженню рівнів енергетичних ризиків, підвищенню прибутковості тощо.

Станом на 2021 р. в Україні й надалі спостерігається досить низький рівень диверсифікування джерел та напрямів (шляхів) постачання первинних енергоресурсів. Хоча перші кроки було зроблено ще у 2014 р. із диверсифрікування джерел (шляхів) постачання, видів енергетичних ресурсів. Але частка відновлювальних джерел (див. рис. 2) у структурі енергетичного балансу (у порівнянні із розвиненими країнами ЄС) досі є низькою.

Потрібно переймати досвід країн (адаптуючи його до національних особливостей), де альтернативна енергетика виступає осно- вним напрямом енергетичного розвитку, зокрема підвищуючи рівень інвестування відновлювальної енергетики. Однак, це потрібно робити у поєднанні із моніторингом рівня їх еорективності, прозорості тощо.

Яскравим прикладом для наслідування виступають процеси реалізування положень Європейської Зеленої Угоди [14] (прийнятої Європейською Комісією ще у грудні 2019 р.), які $€$ спрямованими на забезпечення процесу кліматично-нейтрального розвитку економік до 2050 р. А одним зі стратегічних напрямків, окрім постачання чистої, безпечної і доступної енергії, $€$ форомування і розвиток так званої «розумної» («smart») енергетичної інфрраструктури.

Диверсифікування в енергетичному секторі України повинно відбуватися еволюційно (чітко синхронізовано із розвитком економіки), структуровано (поетапно, аналізуючи бізнессередовище, сприятливі ринкові тенденції у світовій енергетиці, оцінюючи потенціал сорери, рівень ризиковості тощо), комплексно (поєднуючи цілі, мотиви, умови енергетичного диверсифікування), багатоаспектно (поєднуючи різні напрямки розвитку), цілеспрямовано (ідентифрікування цілей диверсиорікування), емерджентно (оновлення енергетичної системи, набуття новітніх властивостей тощо), динамічно (постійний розвитку енергетичної сорери країни), синергійно (взаємодія зі стратегіями розвитку країни) та ін.

Висновки. Диверсифікування шляхів та самих джерел енергопостачання в Україні повинне відбуватися виключно за ринковими, конкурентними засадами. Український вибір сьогодні матиме вирішальне значення для гармонійного розвитку енергетики, економіки, покращення клімату вже через кілька років. Гармонійний розвиток економіки країни можливий лишень за умови координування, прискорення зусиль для просування енергетичного трансформування.

\section{СПИСОК ВИКОРИСТАНИХ ДЖЕРЕЛ:}

1. Амоша А.И., Федоренко В.Г., Белопольский Н.Г., Турченко Д.К. Экономические подходы к эффективному использованию энергетических ресурсов. Економіка та держава. 2008. № 1. С. 4-7.

2. Богуславський Є.І., Черниченко А.О. Вибір оптимального методу диверсифікації підприємства. Ефрективна економіка. 2013. № 10. URL: http://www.economy.nayka.com.ua/?op=1\&z=2424

3. Борисяк О.В., Іванечко Н.Р. Формування цифрового комунікативного середовища з надання енергетичних послуг на засадах кліматично нейтрального розвитку. Бізнес Інорорм. 2021. № 3. С. 44-50.

4. Домашенко М.Д., Школа В.Ю., Троян М.Ю., Домашенко В.С. Розвиток альтернативних (чистих) джерел енергії: досвід ЄС. Бізнес Інформ. 2021. № 4. С. 48-53.

5. Дрималовська Х.В., Кузьмін О.Є., Передало Х.С. Чинники впливу на диверсифрікацію діяльності підприємств. Менеджмент та підприємництво в Україні: етапи становлення і проблеми розвитку. 2013. № 769. C. 143-148. 
6. Енергетична стратегія України до 2035 р.: безпека, енергоефективність, конкурентоспроможність. URL: http://mpe.kmu.gov.ua/minugol/control/uk/doccatalog/list?currDir=50358 (дата звернення: 30.10.2021).

7. Завербний А.С., Шпак Ю.Н. Проблеми гармонійного розвитку енергозабезпечення та енергоефективності економіки в умовах євроінтеграції. ECONOMICS: time realities. 2019. № 4(44). C. 40-48.

8. Климчук О.В., Козловський С.В., Лавров Р.В. Стратегічні аспекти економіко-енергетичної політики України в контексті сталого розвитку. Бізнес Інформ. 2021. № 1. С. 65-76.

9. Корінько М.Д. Диверсифікація як економічний процес. Актуальні проблеми економіки. 2007. № 4. С. 48-53.

10. Офіційний сайт Міністерства енергетики України. URL: https://www.mpe.gov.ua (дата звернення: 25.10.2021).

11. Офіційний сайт Державної служби статистики України. URL: http://www.ukrstat.gov.ua/ (дата звернення: 25.10.2021).

12. Постанова КМУ «Про затвердження Державної цільової економічної програми енергоефективності і розвитку ссрери виробництва енергоносіїв з відновлюваних джерел енергії та альтернативних видів палива на 2010-2021 рр.» від 01.03.2010 р. № 243. URL: https://zakon.rada.gov.ua/laws/show/243-2010-п\#Техt (дата звернення: 25.10.2021).

13. Яковенко В.С., Гаркуша В.В. Тенденції розвитку ринку генерації сонячної енергії України. Бізнес Інфрорм. 2021. № 4. С. 114-119.

14. The European Green Deal. European Commission. Brussels, 11.12.2019. URL: https://ec.europa.eu/info/ sites/info/files/european-green-deal-communication_en.pdf (дата звернення: 25.10.2021).

\section{REFERENCES:}

1. Amosha, A.I., Fedorenko, V.G., Belopolskii, N.G. \& Turchenko, D.K. (2008) Ekonmicheskie podhody k efektivnomu ispolzovaniu energrticheskikh resursov [Economic approaches to the efficient use of energy resources]. Ekonomika ta derzava, 1, 4-7. (in Russian)

2. Boguslavskii, Ye.I., Chernichenko, A.O. (2013) Vybir optymalnogo metodu dyversyfikacii pidpryiemstva [Choosing the optimal method of enterprise diversification]. Efektyvna ekonomika, 10. Available at: http://www.economy.nayka.com.ua/?op=1\&z=2424

3. Borysiak, O.V., Ivanchenko, N.R. (2021) Formuvannia cyfrovogo komunikatyvnogo seredovyshcha z nadania energetychnyh poslug na zasadakh klimatychno nejtralnogo rozvytku [Formation of a digital communicative environment for the provision of energy services on the basis of climate-neutral development]. Biznes Inform, 3, 44-50. (in Ukrainian)

4. Domashenko, M.D., Shkola, V.Yu., Troian, M.Yu. \& Domashenko, V.S. (2021) Rozvytok alternatyvnykh (chystykh) dzerel energii: dosvid ES [Development of alternative (clean) energy sources: EU experience]. Biznes Inform, 4, 48-53. (in Ukrainian)

5. Drymalovska, K.V., Kyzmin, O.Ye. \& Peredalo, K.S. (2013) Chynnyky vplyvu na dyversufakaciu diialnosti pidpruiemstv [Factors influencing the diversification of enterprises]. Menedzment ta pidpryiemnyctvo $v$ Ukraini: etapy stanovlennia i problemy rozvytku [Management and entrepreneurship in Ukraine: stages of formation and problems of development], 769, 143-148. (in Ukrainian)

6. Energetychna strategia Ukrainy do 2035 r.: bezpeka, enerfoefektyvnist, konkurentospromoznist [Ukraine's energy strategy until 2035: security, energy efficiency, competitiveness]. Available at: http://mpe.kmu.gov.ua/ minugol/control/uk/doccatalog/list?currDir=50358 (accessed 25 October 2021).

7. Zaverbnyi, A.S., Shpak, Yu.N. (2019) Problemy garmonijnogo rozvytku energozabezpechenia ta energoefektyvnosti ekonomiky $v$ umovakh yevrointegracii [Problems of harmonious development of energy supply and energy efficiency of the economy in the conditions of European integration]. ECONOMICS: time realities, 4(44), 40-48. (in Ukrainian)

8. Klymchuk, O.V., Kozlovskyj, S.V. \& Lavrov R.V. (2021) Strategichni aspekty ekonomiko-energetychnoi polityky Ukrainy $v$ konteksti stalogo rozvytku [Strategic aspects of economic and energy policy of Ukraine in the context of sustainable development]. Biznes Inform, 1, 65-76. (in Ukrainian)

9. Korinko, M.D. (2007) Dyversyfakacia yak ekonomichnyi proces [Diversification as an economic process]. Aktyalni problemy ekonomiky, 4, 48-53. (in Ukrainian)

10. Oficijnyj sajt Ministerstva energetyky Ukrainy [Official site of the Ministry of Energy of Ukraine]. Available at: https://www.mpe.gov.ua (accessed 25 October 2021).

11. Oficijnyj sajt Derzavnoi sluzby statystyky Ukrainy [Official site of the State Statistics Service of Ukraine]. Available at: http://www.ukrstat.gov.ua/ (accessed 25 October 2021). 
12. Postanova KMU «Pro zatverdzenia Derzavnoi cilovoi ekonomichnoi programy energoefektyvnosti i rozvytku sfery vyrobnyctva energonosiiv z vidnovliuvalnykh dzerel energii ta alternatyvnykh vydiv palyva na 2010-2021 rr.» [Resolution of the Cabinet of Ministers «On approval of the State target economic program of energy efficiency and development of energy production from renewable energy sources and alternative fuels for 2010-2021»] № 243. Available at: https://zakon.rada.gov.ua/laws/show/243-2010-n\#Text (accessed 25 October 2021).

13. Yakovenko, V.S., Garkusha, V.V. (2021) Tendencii rozvytku rynku generacii soniachnoi energii Ukrainy [Trends in the development of the solar energy generation market in Ukraine]. Biznes Inform, 4, 114-119. (in Ukrainian)

14. The European Green Deal. European Commission. Brussels, 11.12.2019. Available at: https://ec.europa.eu/ info/sites/info/files/european-green-deal-communication_en.pdf (accessed 25 October 2021). 